\title{
Significant records of Fijian mosses
}

\author{
Allan J. Fife ${ }^{1}$ and Alifereti Naikatini ${ }^{2}$ \\ ${ }^{1}$ The Allan Herbarium, Landcare Research, PO Box 40, Lincoln 7640, New Zealand. \\ ${ }^{2}$ Institute of Applied Science, Faculty of Science and Technology, University of the South Pacific, \\ Private Bag, Laucala Campus, Suva, Fiji. \\ Author for correspondence: fifea@landcareresearch.co.nz
}

\begin{abstract}
Information about recent collections of 17 taxa of Fijian mosses is presented. One new combination - Calyptrochaeta subremotifolia (Broth.) Fife - is made. Five species Calymperes schmidtii Broth., Dicnemon spathoideum Duby, Cryptogonium phyllogonioides (Sull.) Isovita, Distichophyllum cuspidatum Dozy \& Mölk., and Calyptrochaeta subremotifolia (Broth.) Fife - are newly recorded from Fiji. Four species — Bryobrothera crenulata (Broth. \& Paris) Thér., Trachyloma indicum Mitt. var. indicum, Distichophyllum graeffeanum (Müll.Hal.) Broth., and Daltonia contorta Müll. Hal. — are newly recorded from Taveuni Island.
\end{abstract}

\section{Introduction}

The moss flora of the Fijian islands remains poorly documented and the scattered nature of the literature dealing with it remains an impediment to improving our understanding. The most useful catalogues are those for Melanesia (Schultze-Motel 1973) and the preliminary Fijian checklist (Whittier 1975). Arguably the most useful floristic treatments are those for (1) the Huon Peninsula of Papua New Guinea (Koponen \& Norris 1983; the series partially indexed by Koponen et al. 1991), (2) the treatment of the Samoan mosses by Schultze-Motel (1974) and (3) the unfortunately incomplete 'Malesian Mosses' by Eddy (1988, 1990, 1996). The older but still very useful 'Mosses of the Philippines' (Bartram 1939) also describes and illustrates many taxa occurring in Fiji. A brief discussion of publications dealing specifically with Fijian collections is provided elsewhere (von Konrat et al. 2011, this issue). Other records are largely scattered among monographic or regional treatments (e.g. During 1977, Touw 2001).

The first author has collected material during three recent visits to Fiji. The first, in September 2006, permitted a modest number of collections to be made, mainly from the Suva and Naitasiri provinces of Viti Levu. The second, in April 2007, permitted joint collections from Namosi Province (including Mt Voma) and Suva Province of Viti Levu. The third, in April 2008, allowed collections from Tavua Province (including the western flank of Tomanivi/Mt Victoria), the Rairaimatuku Plateau in the Central 
Highlands of Viti Levu, and from Mt Des Voux and other sites on Taveuni Island. Additionally, we have been able to examine collections made by S. and T. Pócs in 2003 (mostly from the Rairaimatuku Plateau and Mt Des Voux).

A number of the collections made from these localities are of taxa previously unrecorded from the Fijian Islands or taxa poorly documented from Fiji. Study of certain collections also highlighted taxonomic difficulties that can perhaps only be resolved in the context of a regional revision or monograph. These records are presented here in the hope that they will spur further investigations on Fijian mosses.

\section{Species collected}

\section{Calymperaceae}

\section{Calymperes schmidtii Broth.}

Viti Levu: Suva Prov., Mt Korobamba, on lower slopes via track to summit from cement factory at Lami, partly shaded volcanic rock in moderately disturbed lowland rainforest (with Spathodea, Ficus, Cyathea, and Dicksonia conspicuous), c. $75 \mathrm{~m}$ elev., $18^{\circ} 05^{\prime} \mathrm{S} 178^{\circ} 23^{\prime} \mathrm{E}$, Allan Fife 12270 with USP Workshop, 19 Apr 2007 (CHR 595098, SUVA).

A new record for Fiji. The distribution and distinguishing features of this species are discussed by Eddy (1990: 110).

\section{Syrrhopodon croceus Mitt.}

Viti Levu: Namosi Prov., headwaters of the Nabukavesi R., c. $4 \mathrm{~km}$ from Nabukavesi Village on Namosi Rd, on large upper branches of recently fallen tree (Trichospermum sp.?) in dissected second-growth lowland rainforest dominated by Trichospermum and Endospermum and with numerous Cyathea and Angiopteris in understorey, c. $100 \mathrm{~m}$ elev., $18^{\circ} 07^{\prime} \mathrm{S} 178^{\circ} 13^{\prime} \mathrm{E}$, Allan Fife 12305 with M. Tuiwawa, 22 Apr 2007 (CHR 595130, SUVA).

Recorded by Dixon and Greenwood (1930) from a Graeffe collection from Ovalau Island. One Viti Levu locality from near Suva was recorded by Bartram (1936). Considered widespread in Malesia by Eddy (1990: 62), this species is recognised in part by the red pigmentation of its leaf bases.

Syrrhopodon tristichus Nees ex Schwägr.

Viti Levu: Namosi Prov., Mt Voma, on summit cone of Mt Voma via track starting at Namosi Village, on exposed vertical basalt rock face, in seepage with Dicnemon spathoideum, c. $800 \mathrm{~m}$

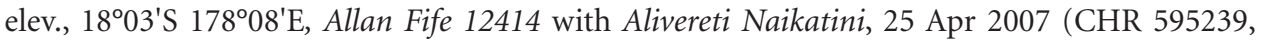
SUVA).

This striking species is apparently recorded from Fiji only by Sullivant (1859) and Mitten (1861). However Mitten (1873) described S. laevigatus Mitt. with syntypes from Ovalau Island (Milne) and Samoa (Powell) and included 'S. tristichum Mitt.' as a synonym. Syrrhopodon laevigatus Mitt. was subsequently recorded from Fiji by several authors, including Dixon and Greenwood (1930: 273) but the relationship between these taxa is not clear. Schultze-Motel (1973) retained both species in his catalogue. Bartram's (1936) S. smithii from Vanua Levu may prove to be synonymous. Syrrhopodon tristichus is considered by Eddy (1990: 80) to be 'widespread in the Indo-Pacific' and to occur throughout Malesia...[mostly] 'between c. 1000 and 2000 m alt.' 


\section{Dicnemonaceae}

Dicnemon spathoideum Duby.

Viti Levu: Namosi Prov., Mt Voma, on summit cone via track starting at Namosi Village; on exposed vertical basalt rock face, in seepage with Syrrhopodon tristichus, $800 \mathrm{~m}$ elev., $18^{\circ} 03^{\prime} \mathrm{S}$ $178^{\circ} 08^{\prime} \mathrm{E}$, Allan Fife 12415 with Alivereti Naikatini, 25 Apr 2007 (CHR 595239, SUVA).

A new record for Fiji and apparently the first record of the species outside of New Caledonia (see Allen 1989: 262). This material differs from the New Caledonian specimens in CHR and NSW by two features. Firstly, the Mt Voma material has the branch leaves markedly spirally twisted in their upper portions. The tendency for spirally twisting is much less in New Caledonian material but is observable in M.R. Crosby 14117 (CHR 412934). Secondly, the Mt Voma material is a striking red nearly throughout, while New Caledonian material is yellow-green. The strong red pigmentation of the Mt Voma collection is probably a result of its strongly insolated, epilithic, and irrigated habitat. Similar pigments have been seen in some populations of Dicnemon sect. Dicnemon in New Zealand. The accumulation of secondary pigments is a common response of many moss species to both irrigation and high levels of insolation. We have not seen type material of D. spathoideum.

\section{Bryaceae}

\section{Brachymenium nepalense Hook.}

Viti Levu: Naitasiri Prov., Qulewai and Monasavu Road Junction, on stem of dead liane in secondary forest in deeply incised stream gully, c. $700 \mathrm{~m}$ elev., $17^{\circ} 44^{\prime} \mathrm{S}$ $178^{\circ} 05^{\prime} \mathrm{E}$, Allan Fife 12155a with M. Tuiwawa, 2 Sep 2006 (CHR 586994, SUVA); Central Highlands, Rairaimatuku Plateau, Monasavu area, c. 7 km S of Monasavu Dam, AlphitoniaHomalium-Metrosideros-Scaveola-Cyathea cloud forest with scattered emergent Dacrydium, on dead branch, $930 \mathrm{~m}$ elev., 17²4'S 178 02'E, Allan Fife 12589, 15 Apr 2008 (CHR 587950).

Previously recorded in Fiji only by Greenwood (1945) from Loma Lega Mountain near Nadarivatu Village, Viti Levu.

\section{Cyrtopodiaceae}

Bescherellia cryphaeoides (Müll.Hal.) M.Fleisch.

Viti Levu: Namosi Prov., Mt Voma, track to summit starting at Namosi Village, on dry vertical basalt in mid-elevation rainforest with Agathis, Trichospermum, Endospermum, and Dendrocnide common in canopy and numerous Ficus spp., Cyathea spp., and Dillenia biflora in understorey, very steep $\left(\mathrm{c} .45^{\circ}\right)$ slope with numerous small cascading streams and small waterfalls and seepages (after recent rain), c. $700 \mathrm{~m}$ elev., $18^{\circ} 03^{\prime} \mathrm{S} 178^{\circ} 08^{\prime} \mathrm{E}$, Allan Fife 12383 with Alivereti Naikatini, 25 Apr 2007 (CHR 595207, SUVA).

Recorded by Dixon and Greenwood (1930: 282) from a single uncertain collection from Ovalau (Graeffe). Recorded from Vanua Levu by Bartram (1936: 12) and by Greenwood (1945: 215) from Nadarivatu, Viti Levu. This appears to be an uncommon species in Fiji. 


\section{Pterobryaceae}

\section{Trachyloma indicum Mitt. var. indicum.}

Taveuni Island: Mt Des Voux, near start of track to Tagimaucia Lake, epiphytic on Scaveola; c. 1180 m, 16 ${ }^{\circ} 50^{\prime} \mathrm{S} 179^{\circ} 58^{\prime} \mathrm{W}$, Allan Fife 12527, 10 Apr 2008 (CHR 587974); Viti Levu: Central Highlands, Rairaimatuku Plateau, Monasavu area, c. 7 km S of Monasavu Dam, AlphitoniaHomalium-Metrosideros-Scaveola-Cyathea cloud forest with scattered emergent Dacrydium, on caudex of Cyathea, with Spiridens aristifolius, $930 \mathrm{~m}$ elev., 17²49'S $178^{\circ} 02^{\prime} \mathrm{E}$, Allan Fife 12589, 15 Apr 2008 (CHR 587973).

A new record for Taveuni Island. The only previous Fijian records are one record each from Vanua Levu and Viti Levu (Tomanivi) by Miller and Manuel (1982), who also record this widespread species from Samoa.

\section{Phyllogoniaceae}

Cryptogonium phyllogonioides (Sull.) Isovita.

Viti Levu: Namosi Prov., Mt Voma, on track starting at Namosi Village; trunk of small dead tree in mid-elevation rainforest on very steep slope, $500 \mathrm{~m}$ elev., $18^{\circ} 03^{\prime} \mathrm{S} 178^{\circ} 08^{\prime} \mathrm{E}$, Allan Fife 12367 with Alivereti Naikatini, 25 Apr 2007 (CHR 595191, SUVA).

A new record for Fiji.

\section{Symphysodontaceae}

\section{Chaetomitrium rugifolium (Sull.) Mitt.}

Viti Levu: Namosi Prov., Wainikatama Stream, c. 5 km SE of Namosi Village on Namosi Rd; on stem of melastome shrub at grazed margin of swift, bouldery, and clear stream in lowland rainforest with Agathis, Trichospermum, and Endospermum in canopy, and Cyathea spp. Ficus spp. and Dillenia biflora in understorey; basalt bedrock, $380 \mathrm{~m}$ elev., $18^{\circ} 01^{\prime} \mathrm{S} 178^{\circ} 10^{\prime} \mathrm{E}$, Allan Fife 12335 with Alivereti Naikatini, 24 Apr 2007 (CHR 595159, SUVA). Taveuni Island: Mt Des Voux, pendent from branches of understorey rubiaceous shrub in primary rainforest, $750 \mathrm{~m}$ elev., $16^{\circ} 50^{\prime}$ S $179^{\circ} 58^{\prime} \mathrm{W}$, Allan J. Fife 12548, 10 Apr 2008 (CHR 587951).

Of the two species of this genus recorded for Fiji by Dixon and Greenwood (1930), we have assigned material to this species, which Mitten (1873: 392) recorded from 'Viti' (presumably Viti Levu) and from Ovalau. No herbarium material for critical comparison was available. We have been influenced by the markedly rugose leaves. Schultze-Motel (1974) recorded this species from Samoa (as C. rugosum W.SchultzeMotel, nom. inval.) Schultze-Motel (1973) listed three other species of Chaetomitrium from Fiji, all on the basis of reports by Bartram.

\section{Pilotrichaceae}

\section{Cyclodictyon blumeanum (Müll.Hal.) Kuntze.}

Viti Levu: Central Highlands, Rairaimatuku Plateau, Monasavu area, headwaters of Waikuru Creek, on basalt in cascading forest stream, subject to periodic flooding, $870 \mathrm{~m}$ elev., $17^{\circ} 49^{\prime} \mathrm{S}$ $178^{\circ} 02^{\prime}$ E, Allan Fife 12663, 16 Apr 2008, CHR 587952, SUVA); Tavua Prov., Northern Highlands, western flank of Tomanivi (Mt Victoria), on track from Navai Village, on damp basalt bedrock in gully of forest rivulet, mid-elevation rainforest, $1050 \mathrm{~m}$ elev., 17³7'S 17801'E, Allan Fife 12718 with E. Namatalau, 18 Apr 2008 (CHR 587953, SUVA). 
This species has been previously recorded from the Monasavu area by Matsui and Iwatsuki (1993), from one Ovalau locality and two Viti Levu localities by Dixon and Greenwood (1930: 289) and from one Vanua Levu locality by Bartram (1936: 16).

\section{Adelotheciaceae}

Bryobrothera crenulata (Broth. \& Paris) Thér.

Taveuni Island: NE side of Mt Des Voux, corticolous in 4-8 m tall elfin forest, 1040-1150 m elev., S. \& T. Pócs 3279/Y, 16 50'S 17958'W, 27 Aug 2003 (CHR 587972, EGR). Det. by G. Kis of EGR.

A new record for Taveuni Island; this appears to be the third Fijian record. Bartram (1936: 9) described Calomnion dixonii from the summit of Tomanivi/Mt Victoria and subsequently reduced it to synonymy under Bryobrothera crenulata (Bartram 1953). Norris and Robinson (1979) also recorded this species from Tomanivi at an elevation of between 800 and $1000 \mathrm{~m}$. They reviewed the then current knowledge of this iconic genus, described its previously unknown sporophyte and concluded that it belonged in the Hookeriaceae sensu Brotherus rather than to the Rhizogoniaceae. Buck and Goffinet (2000) have more recently assigned it to the segregate family Adelotheciaceae. This species was known for nearly a half-century only from New Caledonia following its original description, but Norris and Robinson (1979) recorded its range to include northern Queensland (where it is 'apparently an abundant moss growing primarily on twigs and small branches in ridge top rainforest'), Fiji, and the Solomons. Tan and Koponen (1989) subsequently recorded it from Mindanao Island in the Philippines.

\section{Daltoniaceae}

\section{Daltonia contorta Müll. Hal.}

Taveuni Island: NW slope of Mt Des Voux, on decaying bark in mossy elfin forest very rich in epiphytes, 1040-1150 m elev. 1650'S 17958'W, S. \& T. Pócs 3279/AD, 27 Aug 2003 (EGR); Viti Levu: Central Highlands, Rairaimatuku Plateau, Monasavu area, c. 7 km S of Monasavu Dam, on woody Piper sp. at margin of cloud forest, $930 \mathrm{~m}$ elev., $17^{\circ} 49^{\prime} \mathrm{S} 178^{\circ} 02^{\prime} \mathrm{E}$, Allan Fife 12603 , 15 Apr 2008 (CHR 587977); Central Highlands, Rairaimatuku Plateau, Monasavu area, c. 5 km $\mathrm{S}$ of Monasavu Dam, on damp Coriaria trunk at margin of 4WD track through cloud forest, 1180 m elev., $17^{\circ} 49^{\prime} \mathrm{S} 178^{\circ} 02^{\prime} \mathrm{E}$, Allan Fife 12624, 15 Apr 2008 (CHR 587976).

A new record for Taveuni Island. Recorded by Bartram (1950: 30) from Viti Levu and by Matsui and Iwatsuki (1993) from Viti Levu (Tomanivi) and Vanua Levu. The stout leaf border (c. $60 \mu \mathrm{m}$ and c. 10 cells wide) at the widest part of the leaf, the plane leaf margins and the strongly twisted dry leaves necessitate referral to this species. Matsui and Iwatsuki (1993) list the distribution as 'India, Sri Lanka, Java, Vietnam, Philippines, New Guinea, Fiji, and Hawaii'.

\section{Distichophyllum cuspidatum Dozy \& Mölk.}

Taveuni Island: NW slope of Mt Des Voux, ramicolous in montane rainforest rich in epiphytes, 600-700 m elev., 16050'S 17958'W, S. \& T. Pócs 03288/Q, 1 Sep 2003 (CHR 587955, EGR); Mt Des Voux, near start of track to Tagimaucia Lake, caudex and rachis of dead Cyathea frond, 1170 m, 16 ${ }^{\circ} 50^{\prime} \mathrm{S} 179^{\circ} 58^{\prime} \mathrm{W}$, Allan Fife 12538, 10 Apr 2008 (CHR 587956); Viti Levu: Naitasiri Prov., Qulewa and Monosavu Road Junction $17^{\circ} 44^{\prime} \mathrm{S} 178^{\circ} 05^{\prime} \mathrm{E}$, on roots of Piper aduncum in deeply incised stream gully; c. 700 m elev., Allan Fife 12150 with M. Tuiwawa, 2 Sep 2006 (CHR 586990); Tavua Prov., Northern Highlands, western flank of Tomanivi (Mt Victoria), on track from Navai Village, epiphytic on Piper in mid-elevation rainforest, $1050 \mathrm{~m}$ elev., $17^{\circ} 37^{\prime} \mathrm{S}$ 
178 01'E, Allan Fife 12720 with E. Namatalau, 18 Apr 2008 (CHR 12720); Namosi Prov., Namosi Rd, c. $8 \mathrm{~km} \mathrm{NW}$ of Queens Rd, on dead woody stem in hyper-moist lowland rainforest of stream gully, 80 m elev., $18^{\circ} 07^{\prime} \mathrm{S} 178^{\circ} 11^{\prime} \mathrm{E}$, Allan Fife 12785, 22 Apr 2008 (CHR 587958).

A new record for Fiji. This species is widespread in Malesia and recorded from Sri Lanka (Bartram, 1939), the Society Islands and Micronesia (Whittier 1976: 281). Given the number of collections from a broad elevational range, it is possible that one of the other Distichophyllum spp. recorded from Fiji will prove to be a regional synonym.

Distichophyllum graeffeanum (Müll.Hal.) Broth.

Taveuni Island: near summit of Mt Des Voux, 1190 m elev., 165' S 179 58' W, Allan Fife 12544, 10 Apr 2008 (CHR 587959, SUVA); NE side to Mt Des Voux, in 4-8 m tall elfin forest, 1040-1150 m elev., S. \& T. Pócs 3279/AJ, 1650'S 17958'W, 27 Aug 2003 (CHR 587961, EGR); Viti Levu: Central Highlands, Rairaimatuku Plateau, Monasavu area, c. 7 km S of Monasavu Dam, Alphitonia-Homalium-Metrosideros-Scaveola-Cyathea cloud forest with scattered emergent Dacrydium. 930 m elev., 17²4'S 17802'E, Allan Fife 12595, 15 Apr 2008 (CHR 587960); Central Highlands, NE edge of Rairaimatuku Plateau, above Naqelewai Village, montane mossy cloud forest, 855-945 m elev., S. \& T. Pócs 3273/K, 24 Aug 2003 (CHR 587962, EGR).

A new record for Taveuni Island. Several other collections from nearby localities have also been seen. Previously recorded from Viti Levu by Dixon and Greenwood (1930: 288) on the basis of a Graeffe collection which is presumably the type. Müller's (1874) earlier report is based on the same collection. Also recorded by Gepp (1909, quoted by Schultze-Motel 1973) from an unspecified locality and from Namosi Forest by Matsui and Iwatsuki (1993). The differences between the Fijian D. graeffeanum and Javanese D. osterwaldii are not clear. Brotherus (1925: 230) suggests that these species may differ by their sexuality, the nature of their dry leaves, and ill-defined differences in the ornamentation of the setae and calpytra (with D. graeffeanum being autoicous, with the dry leaves merely wavy and crenulate; the setae spinose, and the calyptra papillose to spinose). The Malesian name D. undulatum Dozy \& Mölk. may also be relevant here. Of these species, only D. graeffeanum has been recorded from Fiji (fide Schultze-Motel 1973 ) and it is appropriate to employ this regional name until a thorough taxonomic revision is published.

Calyptrochaeta subremotifolia (Broth.) Fife, comb. nov.

Basionym: Eriopus subremotifolius Broth., Denkschr. Kaiserl. Akad. Wiss., Math.Naturwiss. Kl. 84: 395 (1908).

Taveuni Island: Mt Des Voux, forming turf of c. $1 \mathrm{~m}^{2}$ on gravel and weathered basalt in bed of intermittent streamlet, $750 \mathrm{~m}$ elev., 16050'S 17958'W, Allan Fife 12553, 10 Apr 2008 (CHR 587963, SUVA); Viti Levu: on the ridge of Rairaimatuku Plateau, $10 \mathrm{~km}$ SSE of Navai, corticolous

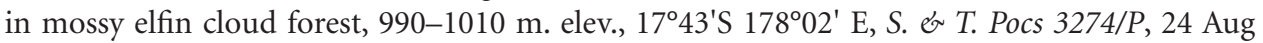
2003 (EGR, CHR 587965); Central Highlands, Rairaimatuku Plateau, c. 2 km NE of Monasavu Dam, on dead standing Ficus stem in highly disturbed and adventive forest, $920 \mathrm{~m} \mathrm{elev.,} 17^{\circ} 45^{\prime} \mathrm{S}$, 17804'E, Allan Fife 12677, 16 Apr 2008 (CHR 587964).

A new record for Fiji and previously recorded only from Samoa. The leaf border here is mostly 2 cells wide. We have little herbarium material for comparison. The differences between C. subremotifolia and C. remotifolia (widespread in Malesia, but also apparently unreported from Fiji) appear to be slight, with Schultze-Motel (1974: 389, as Eriopus) stating that C. subremotifolia has borders of "nur etwa 2 Zellen breiten" while C. remotifolia has borders of 3-5 cell rows. A Samoan specimen available for 
comparison (CHR 349133) has more weakly developed costae and more slender leaf apices than the Fijian.

\section{Sematophyllaceae}

Meiothecium hamatum (Müll.Hal.) Broth.

Viti Levu: Central Highlands, Rairaimatuku Plateau, c. $6 \mathrm{~km} \mathrm{~S}$ of Monosavu Dam, near Madelidovukula Peak, on Coriaria with Macromitrium sp., at margin of road through Podocarpus-Cyathea-Metrosideros-Alpinia cloud forest, $1100 \mathrm{~m}$ elev., $17^{\circ} 49^{\prime} \mathrm{S} 178^{\circ} 02^{\prime} \mathrm{E}$, Allan Fife 12608, 15 Apr 2008 (CHR 587969); Central Highlands, Rairaimatuku Plateau, Monosavu Dam Depot site; epiphytic on ornamental shrub, c. $800 \mathrm{~m}$ elev., $17^{\circ} 49^{\prime} \mathrm{S} 178^{\circ} 02^{\prime} \mathrm{E}$, Allan Fife 12631, 16 Apr 2008 (CHR 587970); NE edge of Rairaimatuku Plateau, above Naqelewai Village, ramicolous in montane mossy cloud forest, 855-945 m elev., S. \& T. Pócs 3273/O, 24 Aug 2003 (CHR 587971, EGR).

Previously recorded from two Fijian sites at comparable elevations in Namosi Prov. by Bartram (1936: 19). Meiothecium hamatum is distinct by its reflexed leaf apices from congeners that have been recorded from Fiji.

Trismegistia rigida (Müll.Hal.) Broth.

Viti Levu: Suva Prov., Colo-i-Suva Forest Park, vicinity of 'upper pools' of Waisila Creek, on exposed root in very wet gorge of cascading stream in modified lowland rain forest, 120-180 m elev., 180.'S', 178²8'E, Allan Fife 12399, 29 Apr 2007 (CHR 595223, SUVA).

This is a common species at this site. Although apparently widespread in the Pacific, this species is recorded from only one unspecified Viti Levu site by Mitten (1873) on the basis of a Milne collection. This record is also quoted by Dixon and Greenwood (1930: 298). Only one other record of a Trismegistia is cited from Fiji by Schultze-Motel (1973).

\section{Acknowledgments}

AJF thanks Marika Tuiwawa and the staff of the USP herbarium for sharing their knowledge of the Fijian flora and culture, and for their excellent hospitality. We thank Marika, John Braggins, Elizabeth Brown, Matt von Konrat, Thorsten Lumbsch, Tamás Pócs and Matt Renner for their company in the field, sometimes under trying physical conditions. Tamás Pócs kindly allowed us to study Fijian collections he made, with his wife, in 2003. Some of these collections had been previously examined by G. Kis at EGR. The curators at EGR and NSW kindly provided loans. We thank David Glenny and Rod Seppelt for helpful comments on a draft of this paper and Christine Bezar for editorial assistance. Grant Hunter and Ilse Breitwieser provided support to AJF in various ways. AJF's 2006 and 2007 visits to Fiji were largely funded by NZAid (Government Agencies Contestable Fund), while his 2008 visit was funded by the National Geographic Committee for Research and Exploration (Grant No. 8247-07 awarded to Matt von Konrat).

\section{References}

Allen BH (1989) The genus Dicnemon (Musci: Dicnemonaceae) in New Caledonia. Hikobia 10: 245-267. 
Bartram EB (1936) Contribution to the mosses of Fiji. Occasional Papers of the Bernice P. Bishop Museum 11: 1-30.

Bartram EB (1939) Mosses of the Philippines. Philippine Journal of Science 68: 1-437, pl. 1-29. (Reprinted by Koeltz, 1972)

Bartram EB (1950) Additional Fijian Mosses II. Occasional Papers of the Bernice P. Bishop Museum 20: 27-33.

Bartram EB (1953) New Caledonian mosses collected by Dr. O.H. Selling. Botaniska Notiser 1953: 197-203.

Brotherus VF (1924-1925) Musci. In Engler A \& Prantl K (eds) Die natürlichen Pflanzenfamilien, ed. 2.2 vols. Bd. 10, 1924, pp. 143-478; Bd. 11, 1925 (Engelmann: Leipzig)

Buck WR \& Goffinet B (2000) Morphology and classification of mosses. Pp. 71-123 in Shaw AJ \& Goffinet B (eds) Bryophyte biology. (Cambridge University Press, Cambridge)

Dixon HN \& Greenwood W (1930) The Mosses of Fiji. Proceedings of the Linnean Society of New South Wales 55(3): 261-302; pls viii-ix.

During HJ (1977) A taxonomical revision of the Garovaglioideae (Pterobryaceae, Musci). Bryophytorum Bibliotheca 12: 1-244.

Eddy A (1988) A handbook of Malesian mosses, vol. 1 Sphagnales to Dicranales. (Natural History Museum Publications, London)

Eddy A (1990) A handbook of Malesian mosses, vol. 2 Leucobryaceae to Buxbaumiaceae. (Natural History Museum Publications: London)

Eddy A (1996) A handbook of Malesian mosses, vol. 3 Splachnobryaceae to Leptostomataceae. (Natural History Museum and HMSO: London)

Greenwood W (1945) Notes on some Fijian mosses. Proceedings of the Linnean Society of New South Wales 70: 213-218.

Koponen T \& Norris DH (1983) Bryophyte flora of the Huon Peninsula, Papua New Guinea. I. Study area and its bryological exploration. Annales Botanici Fennici 20: 15-29.

Koponen T, Piippo S \& Norris DH (1991) Bryophyte flora of the Huon Peninsula, Papua New Guinea. XLVII. Generic and family indexes to parts I-XLVI. Acta Botanica Fennica 143: $107-111$.

Matsui T \& Iwatsuki Z (1993) Callicostaceae and Daltoniaceae (Hookeriales, Musci) from Fiji and Vanuatu. Hikobia 11: 281-284.

Miller NG \& Manuel MG (1982) Trachyloma (Bryophytina, Pterobryaceae): a taxonomic monograph. Journal of the Hattori Botanical Laboratory 51: 273-321.

Mitten W (1861) Musci et Hepaticae Vitiensis. Bonplandia 9: 365-367.

Mitten W (1873) Musci. Pp. 378-404 in Seemann B Flora Vitiensis. (London)

Müller C (1874) Music polynesiaci praesertim Vitiani et Somoani Graeffeani. Journal des Museum Godeffroy 3 (6): 51-90.

Norris DH \& Robinson H (1979) The systematic position of Bryobrothera crenulata. Bryologist 82: 305-309.

Schultze-Motel W (1973) Katalog der Laubmoose von Melanesien. Willdenowia 7: 47-82.

Schultze-Motel W (1974) Die Moose der Samoa-Inseln. Willdenowia 7: 333-408.

Sullivant W (1859) Musci. Pp. 1-112 in United States Exploring Expedition during the years 1838, 1839, 1840, 1841, 1842 under the command of Charles Wilkes, U.S.N. vol. 17.

Tan BC \& Koponen T (1989) Additions and corrections to the Philippine moss flora. Cryptogamie, Bryologie Lichenologie 10: 235-245.

Touw A (2001) A taxonomic revision of the Thuidiaceae (Musci) of tropical Asia, the western Pacific, and Hawaii. Journal of the Hattori Botanical Laboratory 91: 1-136.

von Konrat M, Naikatini A, Tuiwawa M, Söderström L, Fife A, Renner M, Brownsey P, Perrie L, Hagborg A, Pócs T, Lumbsch HT, Braggins J, Séneca A \& Brown E (2011) A brief history of the cryptogams of Fiji and prospects for the future. Telopea 13:361-374.

Whittier HO (1975) A preliminary list of Fijian mosses. Florida Scientist 38(2): 85-106.

Whittier HO (1976) Mosses of the Society Islands. (University Presses of Florida: Gainesville, FL) 